\title{
ПІДХОДИ ДО ВИЗНАЧЕННЯ ПОНЯТТЯ «ДІАСПОРА» ТА ÏÏ ТИПІЗАЦІї
}

\section{Зубик А. I.}

\section{ВСТУП}

Діаспори істотно впливають на країни, у яких вони проживають. Передусім це видно зі зміни демографічної структури, етнічного, мовного та релігійного складу населення. Зростає їхній вплив на внутрішню та зовнішню політику країн проживання, оскільки діаспори можуть лобіювати інтереси історичної батьківщини.

Діаспорам притаманна етнічна самосвідомість, яка зберігається впродовж тривалого часу, почуття солідарності зі співгромадянами на батьківщині та в інших країнах. Додатковим чинником, який дає їм змогу протистояти асиміляції, є підтримка історичної батьківщини і створення своїх організацій.

Процеси глобалізації, розвиток транспорту, соціальних мереж привели до того, що спільноти транснаціональних мігрантів швидше трансформуються в діаспори. Важливу роль відіграють уже сформовані діаспори, які допомагають новоприбулим із легалізацією їхнього статусу, пошуками житла, роботи, правовою допомогою тощо. Варто відзначити роль соціальних мереж: якщо сто років тому джерелом інформації були вербувальники, то зараз іiі можна отримати від співвітчизників, які проживають у цій країні, через листування чи перегляд тематичних блогів. Також соціальні мережі $\epsilon$ способом підтримки зв'язку з батьківщиною чи для координації дій у країні проживання. Унаслідок цього спільноти мігрантів швидше освоюються в новій країні. Водночас з утворенням діаспор виникають цілі мережі їх підтримки. Передусім це вже наявні діаспори співвітчизників, люди, які допомагають із перевезенням, пошуком роботи, житла, документами тощо. У цьому контексті можна говорити про вже усталений бізнес, який часто є нелегальним або напівлегальним.

На утворення діаспор у певній країні впливає рівень іï економічного розвитку, культурна, релігійна та мовна дистанція між іммігрантами та рештою населення, лояльність законодавства та населення до іммігрантів, попит на робочу силу тощо. Результатом дії цих процесів $\epsilon$ притягання/відштовхування іммігрантів i, як наслідок, виникнення діаспор. Стрімкі процеси трансформації іммігрантських спільнот у діаспори зумовили те, що діаспорами почали називати будь-які спільноти, незалежно від характеру та тривалості їх перебування поза 
межами історичної батьківщини. Зважаючи на те, що змінився механізм утворення діаспор, та багатоаспектність цього поняття, необхідно переосмислити його суть та складові частини, які його формують.

\section{1. Підходи до трактування поняття «діаспора»}

Діаспора є об’єктом дослідження багатьох наук, проте досі немає єдиного підходу щодо трактування цього поняття. Для пересічних людей це поняття пов'язане зі спільнотами людей, які проживають/перебувають поза межами своєї батьківщини. Згідно з визначенням, яке наведено в «Історичному словнику», діаспора - це розселення євреїв із часу Вавилонського полону в VI ст. до н. е. поза Палестиною ${ }^{1}$. Проте самі євреї, характеризуючи вимушене переселення, уживають слово «галут», яке означає «важке, болісне життя, рабське становище». Утім, у науці склалася традиція позначати терміни грецькими та латинськими словами, тому

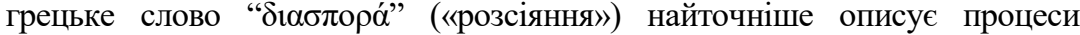
розселення етносів.

Зараз поняття «діаспора» набуває ширшого тлумачення. Його вживають на позначення назви груп, які з певних причин відірвані від основної частини етносу, але, проживаючи в іноетнічному середовищі, підтримують зв'язок з історичною батьківщиною ${ }^{2}$.

У «Малій енциклопедії етнодержавознавства» діаспору визначають як «розселення значної частини представників народу за межами країни його походження. Діаспори утворюються внаслідок насильницького виселення, загрози геноциду, дії низки соціальних, економічних факторів, а в окремих випадках під впливом кліматично-природних катаклізмів» ${ }^{3}$.

Поняття «діаспора» підкреслює факт переважно недобровільного переселення; у процесі розвитку недержавних діаспор відбувається формування ідеології, спрямованої на утворення власної незалежної держави ${ }^{4}$.

Основні підходи до поняття «діаспора» можна звести до двох груп: a) етнічна спільнота, яка перебуває в іноетнічному середовищі; б) громадяни, які мають іноетнічне походження та підтримують зв'язок із батьківщиною.

Перший підхід розглядає проживання частини етносу поза межами батьківщини, яке зберігає свою ідентичність та внутрішню

1 Исторический словарь. URL: http://mirslovarei.com/content_his/Diaspora-1402 (дата звернення: 23.07.2017).

2 Алієва М. Різні тлумачення терміна «діаспора». Етнічна історія народів Європи. Київ, 2008. Вип. 24. С. 63-64.

${ }_{3}$ Мала енциклопедія етнодержавознавства / за ред. Ю. Римаренко. Київ : Генеза, 1999. C. 464. C. 532 .

Курас І. Етнополітологія. Перші кроки становлення. Київ : Генеза, 2004. 
солідарність. Дослідники Г. Шеффер ${ }^{5}$, Дж. Армстронг ${ }^{6}$ і М. Есман ${ }^{7}$ трактують діаспору як похідну від міграції. Тобто діаспорами називають однорідні етнічні спільноти, які розселені не менше як у двох країнах через вимушену міграцію.

За другим підходом, прихильниками якого $є$ Ж. Тощенко і Т. Чаптикова ${ }^{8}$, ознаки діаспори ширші. Зокрема, це перебування частини етносу поза межами батьківщини, а еміграція $є$ одним зі способів формування діаспори. Такий підхід означає, що створювати діаспору може стійкий до асиміляції етнос. Стійкість діаспори досягається завдяки консолідації (через діяльність різних організацій у діаспорі) чи через існування «стрижня» (національна ідея, історична пам'ять, традиції, релігія), який згруповує діаспору9.

Підходи науковців до поняття «діаспора» узагальнено в табл. 1 , iз зазначенням ключових тез і головних ознак (табл. 1). Як бачимо, вживання поняття «діаспора» передбачає наявність супроводжувальних категорій. Наприклад, категорія «історична батьківщина».

У. Коннор (американський науковець, який досліджує проблеми етнічності) визначає діаспору як «сегмент населення, що проживає поза межами батьківщини». Такий підхід охоплює всі іммігрантські спільноти та включає до діаспори іммігрантів, експатріантів, біженців тощо ${ }^{10}$.

Важливою складовою частиною поняття «діаспора» $є$ діаспорна ідентичність. М. Дабаг і К. Платт уважають, що вона підтримується через наявність та діяльність громадських інституцій у діаспорі. Також науковці зазначають, що стиль життя діаспори формується через взаємодію традицій, сучасності, досвіду та спогадів, історії, культури, мови. Участь у цій взаємодії беруть діаспора, країна прийому й історична батьківщина ${ }^{11}$.

5 Шеффер Г. Диаспоры в мировой политике. Диаспоры. Москва, 2003. № 1. C. $162-184$.

${ }^{6}$ Armstong J. A. Mobilized and proletarian Diasporas. American political sciences review. 1976. Vol. 70. № 2. P. 393-408.

Esman M. Diasporas in international relations. Modern Diasporas in international politics. New York, 1986. P. 333-349.

8 Тощенко Ж. Диаспора как объект социологического исследования. Сочис. Москва, 1996. № 12. С. 37-45.

9 Алієва М. Різні тлумачення терміна «діаспора». Етнічна історія народів Свропи. Київ, 2008. Вип. 24. С. 63-64.

10 Коннор У. Диаспоры: транснациональное самосознание и политика в странах исхода. Диаспоры. Москва, 1999. № № 2-3. С. 40-51.

${ }_{11}$ Dahan M. Ethnic groups and distant shrinking communication technologies. Nationalism and ethnic politics. 2001. Vol. 7. № 1. P. 25-40. 
Таблиця 1

Підходи науковців до визначення поняття «діаспора» 12

\begin{tabular}{|l|l|l|}
\hline \multicolumn{1}{|c|}{ Науковець } & \multicolumn{1}{|c|}{$\mathbf{1}$ Ключа теза } & \multicolumn{1}{c|}{ Головні ознаки } \\
\hline Алієва М. & частина етносу & $\begin{array}{l}\text { проживання поза межами батьківщини; } \\
\text { збереження етнічної та релігійної } \\
\text { ідентичності; }\end{array}$ \\
\hline Брубейкер Р. & частина етносу & $\begin{array}{l}\text { емоційний зв'язок з історичною } \\
\text { батьківщиною }\end{array}$ \\
\hline Винницький М. & $\begin{array}{l}\text { етнічна } \\
\text { спільнота }\end{array}$ & $\begin{array}{l}\text { проживання поза межами країни } \\
\text { походження; створення діаспорних } \\
\text { організацій }\end{array}$ \\
\hline Годованська О. & $\begin{array}{l}\text { українська } \\
\text { спільнота }\end{array}$ & $\begin{array}{l}\text { проживання поза межами батьківщини; } \\
\text { відчуття духовного зв’язку з Україною }\end{array}$ \\
\hline Дабаг М., Платт К. & $\begin{array}{l}\text { суспільна } \\
\text { модель }\end{array}$ & $\begin{array}{l}\text { взаємодія традицій, спогадів, культури та } \\
\text { мови }\end{array}$ \\
\hline Есман Дж. & $\begin{array}{l}\text { етнічна } \\
\text { меншина }\end{array}$ & $\begin{array}{l}\text { емоційний зв'язок з історичною } \\
\text { батьківщиною }\end{array}$ \\
\hline Заставний Ф. & $\begin{array}{l}\text { частина } \\
\text { народу/етнічна } \\
\text { спільнота }\end{array}$ & $\begin{array}{l}\text { проживання поза межами країни } \\
\text { походження внаслідок насильницького } \\
\text { виселення, геноциду та дії різних чинників }\end{array}$ \\
\hline Канукова 3. & частина етносу & $\begin{array}{l}\text { проживання поза історичною } \\
\text { батьківщиною; збереження етнічної } \\
\text { самобутності; розвинута діаспорна } \\
\text { структура }\end{array}$ \\
\hline Кім О. & $\begin{array}{l}\text { проживання в іноетнічному середовищі } \\
\text { етнополітичний } \\
\text { феномен }\end{array}$ & \\
\hline
\end{tabular}

${ }_{12}$ Алієва М. Різні тлумачення терміна «діаспора». Етнічна історія народів Свропи. Київ, 2008. Вип. 24. С. 63-64 ; Брубейкер Р. Диаспоры катаклизма в Центральной и Восточной Европе и их отношение с родинами. Диаспоры. Москва, 2005. № 3. С. 44-71 ; Винницький М. Україна і діаспора - можливості формування світового українства. Культурні зв'язки Донеччини з українським зарубіжжсям : матеріали Науковопрактичної конференції, м. Донецьк, 17 грудня 2004 р. Донецьк, 2004. С. 17-22 ; Годованська О. Новітня українська діаспора: трудові мігранти в Італії, Іспанії та Португалії. Львів : Ін-т народознавства НАН України, 2011. С. 16 ; Заставний Ф. Східна українська діаспора. Львів : Світ, 1992. 176 с. ; Канукова 3. Диаспора: функциональный анализ термина. Вестник Владикавказского научного иентра. Владикавказ, 2011. № 4. С. 23-28 ; Карпова Ю. Этнодемографические аспекты миграционных процессов в России и Украине. Соиис. Москва, 2005. № 12. С. 94-102 ; Кондратьева Т. Диаспоры в современном мире: эволюция явления и понятия. URL: http://www.perpectivy.info (дата звернення: 26.06.2017) ; Левин 3. Менталитет диаспоры : системный и социокультурный анализ. Москва : Ин-т востоковедения РАН ; Крафт, 2001. 176 с. ; Професор Володимир Кубійович / упоряд. О. Шаблій. Львів : Видавничий центр ЛНУ імені Івана Франка, 2006. 378 с. ; Семенов Ю. Этнос, нация, диаспора. Этнографическое обозрение. Москва, 2000. № 2. С. 64-73 ; Стрельченко С. Диаспора как субъект социально-экономических процессов современности. Энергия. 2006. № 7. С. 65-68 ; Тишков В. Исторический феномен диаспоры. Этнографическое обозрение. Москва, 2000. № 2. С. 43-63; Тощенко Ж. Диаспора как объект социологического исследования. Социс. Москва, 1996. № 12. С. 37-45 ; Хабибулина Н. Диаспора: сущность, социально-философские аспекты развития: на материалах Бурятии : автореф. дис. ... канд. филос. наук: 09.00.04. УланУдэ, 2003. 20 c. ; Dahan M. Ethnic groups and distant shrinking communication technologies. Nationalism and ethnic politics. 2001. Vol. 7. № 1. P. 25-40. 
Продовження таблиці 1

\begin{tabular}{|c|c|c|}
\hline 1 & 2 & 3 \\
\hline Коен Р. & - & $\begin{array}{l}\text { розсіяння в більше ніж два зовнішні } \\
\text { регіони; пам'ять про батьківщину та намір } \\
\text { повернутися }\end{array}$ \\
\hline Коннор У. & $\begin{array}{l}\text { сегмент } \\
\text { населення }\end{array}$ & проживання поза межами батьківщини \\
\hline Кубійович В. & $\begin{array}{l}\text { частина } \\
\text { українського } \\
\text { етносу }\end{array}$ & $\begin{array}{l}\text { проживання поза межами української } \\
\text { національної території }\end{array}$ \\
\hline Лєвін 3. & частина етносу & $\begin{array}{l}\text { уявлення про єдність походження; групові } \\
\text { характеристики, які відрізняють їх від } \\
\text { решти населення країни призначення }\end{array}$ \\
\hline Лисенко Ю. & частина етносу & перебування в іноетнічному середовищі \\
\hline Полоскова Т. & - & $\begin{array}{l}\text { етнічна ідентичність; спільність } \\
\text { походження та цінностей; збереження } \\
\text { етнічної самобутності }\end{array}$ \\
\hline Семенов Ю. & $\begin{array}{l}\text { етнічний } \\
\text { феномен }\end{array}$ & $\begin{array}{l}\text { спільні культура, мова; відмінність від } \\
\text { інших етнічних спільнот }\end{array}$ \\
\hline Стрельченко С. & $\begin{array}{l}\text { етнічна } \\
\text { меншина }\end{array}$ & $\begin{array}{l}\text { спільна самосвідомість; інститути } \\
\text { внутрішньої консолідації }\end{array}$ \\
\hline Тишков В. & спільнота & $\begin{array}{l}\text { спогади про спільну історичну } \\
\text { батьківщину; групова солідарність; } \\
\text { відносини з історичною батьківщиною }\end{array}$ \\
\hline $\begin{array}{l}\text { Тощенко Ж., } \\
\text { Чаптикова Т. }\end{array}$ & $\begin{array}{l}\text { сукупність } \\
\text { людей єдиного } \\
\text { етнічного } \\
\text { походження }\end{array}$ & $\begin{array}{l}\text { наявність соціальних інститутів для } \\
\text { розвитку та функціонування спільнот }\end{array}$ \\
\hline Хабібуліна Н. & спільнота людей & $\begin{array}{l}\text { соціальні інститути, що забезпечують } \\
\text { захист та підтримку її членів }\end{array}$ \\
\hline
\end{tabular}

Інша ознака діаспори - наявність та підтримка серед представників діаспори колективної пам'яті, міфу про історичну батьківщину, іii історію та досягнення колишніх співвітчизників. Схожою ознакою $є$ ностальгійна віра в батьківщину як ідеальний дім та місце, куди представники діаспори або їхні нащадки повинні повернутися ${ }^{13}$.

Науковець О. Кім уважає, що ознаками діаспори є: 1) етнічна ідентифікація, яка проявляється у зв'язках із країною проживання та батьківщиною; 2) створення організацій із метою збереження етнокультурної самобутності; 3) взаємодія 3 інституціями країни проживання та батьківщини ${ }^{14}$.

${ }^{13}$ Алієва М. Різні тлумачення терміна «діаспора». Етнічна історія народів Європи. Київ, 2008. Вип. 24. С. 63-68 ; Safran W. Diasporas in modern Societies: myths of Homeland and return. Diaspora. 1991. Vol. 1. № 1. P. 83-95.

14 Ким А. Этнополитическое исследование современных диаспор (конфликтологический аспект) : автореф. дис. ... докт. полит. наук. СанктПетербург, 2009. URL: http://vak.ed.gov.ru/common/img/uploaded/files/ vak/annocements/politich/2009/06-04/KimAS.rtf (дата звернення: 26.06.2017). 
У статті «Історичний феномен діаспори» В. Тишков зазначає, що діаспору варто розуміти як переміщення людей на міждержавному рівні в історичній перспективі. Також він зазначає, що діаспора формується не внаслідок кожного переміщення людей, і не всі мігранти, які живуть в іноетнічному середовищі, $\epsilon$ діаспорою. Виникнення діаспор, на його думку, пов'язане 3 переміщенням через кордони, а сприймають їх як групи, які є гомогенними ${ }^{15}$.

На нашу думку, однією із причин неоднозначності трактування поняття «діаспора» $\epsilon$ чинник іiі утворення. Найчастіше діаспори утворюються внаслідок міграції людей, рідше - через зміну державних кордонів. Ідею утворення діаспор внаслідок зміни кордонів висунув $\mathrm{i}$ обгрунтував Р. Брубейкер, який виділив «діаспори катаклізму», що виникли після розпаду великих поліетнічних утворень. Такі діаспори $\epsilon$ результатом зміни державних кордонів, представники «діаспор катаклізму» - громадяни тієї країни, де їх застала зміна кордонів.

Ілюстративним $€$ порівняння «діаспор катаклізму» із трудовими діаспорами. Науковець зазначає, що трудові діаспори утворюються внаслідок переміщення людей через кордони, а «діаспори катаклізму» рухом кордонів. Трудові діаспори формуються поступово, а «діаспори катаклізму» виникають через різку зміну політичного устрою; трудові діаспори створюються завдяки міграціям людей, а «діаспори катаклізму» виникають без участі людей; трудові діаспори розсіяні по території країни прийому, «діаспори катаклізму» проживають компактно; трудові мігранти залишаються постійно чи на деякий час громадянами країни походження, а ті, хто належить до «діаспор катаклізму», є громадянами тієї країни, де їх застала зміна кордонів ${ }^{16}$.

Враховуючи підходи науковців, ми розглядаємо діаспору як частину етносу, що проживає поза межами історичної батьківщини внаслідок суб'єктивних і об'єктивних обставин, зберігає етнічну самобутність i мову, прямо чи опосередковано підтримує зв'язок із країною походження.

У контексті діаспори поняття «українська діаспора» базується на визнанні кордонів України як політичної реальності, факті проживання українців в інших державах. Українській діаспорі притаманні такі ознаки: перебування частини етносу поза межами України; створення через переважно недобровільне переселення; компактне та розсіяне розселення; автохтонне й іммігрантське походження; діаспорні українці, на відміну від українських трудових мігрантів, мають громадянство країни проживання ${ }^{17}$.

15 Тишков В. Исторический феномен диаспоры. Этнографическое обозрение. Москва, 2000. № 2. С. 43-63.

${ }^{16}$ Брубейкер Р. Диаспоры катаклизма в Центральной и Восточной Европе и их отношение с родинами. Диаспоры. Москва, 2005. № 3. С. 47-48.

${ }^{17}$ Трощинський В. Українці у світі. Київ : Альтернативи, 1999, С. 19-24. 
Українську діаспору можна розглядати як:1) етнічну меншину країн проживання; 2) автохтонне населення українських етнічних територій у складі інших країн; 3) частину українського етносу; 4) громадян країн проживання, які мають українське походження.

Український географ Ф. Заставний зазначав, що українська діаспора характеризується різними часом і мотивами поселення в тих чи інших країнах, особливостями розселення, рівнем національної свідомості, часткою в населенні країн проживання, збереженням мови, стійкістю до асиміляції ${ }^{18}$.

На думку О. Годованської, сучасна українська діаспора виконує такі функції: пропагує національні звичаї та обряди, підтримує культурні зв'язки з Україною, зберігає рідну мову як ретранслятор національної культури та засіб проти асиміляції, бере участь у підтримці, розвитку й укріпленні культури, забезпечує соціальний i правовий захист співвітчизників у країні проживання, обстоює свої інтереси для отримання додаткових прав і гарантій ${ }^{19}$.

Для українських науковців важлива проблема осмислення феномену діаспори. Передусім це стосується вживання понять «західна українська діаспора» та «східна українська діаспора». Попри умовний поділ між «західною» та «східною» діаспорами, $\epsilon$ відмінності в розселенні, ступені асиміляції, статево-віковій структурі, освітньому рівні тощо.

Критерії, якими позначали поняття «західна українська діаспора», не завжди і не в усьому підходять для характеристики поняття «східна українська діаспора». Західна українська діаспора у країнах проживання впродовж кількох поколінь розбудувала мережу власних етнічних організацій i установ. Завдяки цьому вона має ліпші можливості для збереження національної ідентичності й продовження свого існування власне як діаспори, незважаючи на майже суцільну інтеграцію в суспільне життя країн проживання ${ }^{20}$.

Разом із поняттям «українська діаспора» уживають поняття «закордонне українство», «закордонні українці», «українці зарубіжжя». Тобто до української діаспори відносять українців, які опинилися поза межами історичної батьківщини, незалежно від причини, як-от: розпад країн, світові війни, природні катаклізми, політичні чи економічні кризи, особисті обставини ${ }^{21}$.

18 Заставний Ф. Східна українська діаспора. Львів : Світ, 1992. С. 30.

${ }^{19}$ Годованська О. Новітня українська діаспора: трудові мігранти в Італії, Іспанії та Португалії. Львів : Ін-т народознавства НАН України, 2011. С. 124.

${ }^{20}$ Курас I. Етнополітологія. Перші кроки становлення. Київ : Генеза, 2004. C. 533-534.

21 Алієва М. Діаспора: історія, історіографія та спроба уточнення поняття. Вісник Київського начіонального університету імені Тараса Шевченка. Історія. Київ, 2006. Вип. 86. С. 65. 
Із поняттям «діаспора» тісно пов'язане (але в інших контекстах) поняття «етнічна меншина». У «Малій енциклопедії етнодержавознавства» зазначено, що етнічна меншина - «це частина етносів, основне ядро яких розташоване за межами держави й існує, як правило, у формі самостійних етнополітичних організмів» ${ }^{22}$. У різних країнах термін «етнічна меншина» уживають у відмінних значеннях: усі народи, крім найчисельнішого; лише іммігрантські групи, на відміну від корінних етносів; усі, хто не сповідує державної релігії; ті етнічні групи, які не мають рівноправного статусу з державною нацією і намагаються досягти його, іноді у формі автономії чи незалежності.

Варто зазначити, що поняття «етнічна меншина» та «діаспора» збігаються лише частково. Поняттям «етнічна меншина» називають групу, кількісно меншу щодо іншого населення держави і яка не має номінованого становища в ній, члени якої - громадяни цієї країни мають низку етнічних, релігійних або лінгвістичних особливостей, що відрізняє ї від іншого населення, та мають почуття солідарності, спрямоване на збереження своєї культури, традицій, релігії та мови. На відміну від етнічних (національних) меншин, «діаспора» не $\epsilon$ правовим поняттям, за нею юридично не закріплена можливість представляти й захищати свої інтереси в системі державних $\mathrm{i}$ міждержавних інститутів ${ }^{23}$.

\section{2. Підходи до типізації діаспор і країн, де проживас українська діаспора}

Для типізації діаспори Дж. Армстронг важливим критерієм iï здійснення вважає спосіб взаємодії діаспори із середовищем проживання та виділяе два типи діаспор: «мобілізовані» та «пролетарські». «Мобілізовані» діаспори формувалися століттями, вони мають здатність до адаптації та інтеграції в суспільство, що приймає. Як зазначає сам дослідник, «такі діаспори не переважають інші етнічні групи в цих країнах, однак мають низку матеріальних та культурних переваг». До категорії «мобілізованих» діаспор він відносить єврейську та вірменську діаспори, називаючи їх архетипічними. «Пролетарські» діаспори - молоді діаспори, які виникли недавно ${ }^{24}$.

Інший підхід використовує Г. Шеффер, який виділив сім типів діаспор:

22 Мала енциклопедія етнодержавознавства / за ред. Ю. Римаренко. Київ : Генеза, 1999. С. 37.

${ }^{23}$ Алієва М. Різні тлумачення терміна «діаспора». Етнічна історія народів Європи. Київ, 2008. Вип. 24. С. 67.

${ }^{24}$ Armstong J. Mobilized and proletarian Diasporas. American political sciences review. 1976. Vol. 70. № 2. P. 393-408. 
1) діаспори зі значним досвідом існування (вірменська, єврейська, китайська);

2) «дрімаючі» діаспори (американці в Свропі чи Азії);

3) «молоді» діаспори (грецька, польська і турецька);

4) «новостворені», які починають лише формуватися (діаспори країн колишнього Радянського Союзу);

5) «бездомні» діаспори, які не мають країни походження (курдська, палестинська);

6) етнонаціональні діаспори - найпоширеніший тип діаспор, особливістю яких є підтримка країни походження;

7) діаспори «розсіяні» та компактно розселені ${ }^{25}$.

Досить детальну типологію діаспор розробив В. Попков, який використав вісім критеріїв:

1) спільність історичного минулого: а) діаспори, члени яких проживають на території своєї колишньої держави; б) діаспори, члени яких раніше не були пов'язані з новою країною єдиним правовим чи мовним середовищем;

2) юридичний статус діаспор: а) діаспори, члени яких мають легальний статус у країні, що приймає; б) діаспори, члени яких нелегально перебувають на території країни, що приймає;

3) чинники формування: а) еміграція частини етносу; б) рух кордону, унаслідок чого частина етносу стає діаспорою;

4) характер мотивації до переселення: а) діаспори, які виникли внаслідок еміграції людей під впливом економічних мотивів; б) діаспори, сформовані внаслідок «витіснення» частини етносу 3 території проживання, через соціальні та політичні зміни чи природні катаклізми;

5) характер перебування на території поселення: а) діаспори, які мають намір постійно проживати на новій території; б) діаспори, які розглядають країну нового поселення як транзитну, звідки вони мігрують до іншої країни чи повернуться на історичну батьківщину; в) діаспори, члени яких налаштовані на безперервну міграцію між країнами походження та призначення;

6) наявність «бази» у країні нового поселення: а) діаспори, члени яких тривалий час проживають у країні поселення та мають досвід взаємодії з титульним етносом; б) діаспори, які виникли відносно недавно і не мають досвіду взаємодії з культурою та суспільством країни, що приймає;

7) «культурна схожість» із країною, яка приймає: діаспори з малою, середньою та великою культурною дистанцією;

25 Шеффер Г. Диаспоры в мировой политике. Диаспоры. Москва, 2003. № 1. C. 165 . 
8) наявність державних утворень на території країни походження: а) діаспори, члени яких мають свою державу; б) «бездержавні» діаспори, члени яких не мають офіційно визнаної держави ${ }^{26}$.

3 огляду на різний ступінь етнічної свідомості, в українській діаспорі виділяють: а) консолідуючі верстви 3 високим ступенем усвідомлення своєї ідентичності; б) верстви, що усвідомлюють своє українське походження, але вже інтегровані в суспільство країни проживання; в) переважно асимільовані групи, які дотримуються деяких українських традицій; г) цілком денаціоналізовані групи, які ще можуть зберігати пам'ять про українське походження ${ }^{27}$.

В українській науці найпоширенішим є поділ української діаспори на східну і західну. Східна українська діаспора складається із країн, які виникли на пострадянському просторі, - Російської Федерації, Казахстану, Молдови, Білорусі, країн середньої Азії, Закавказзя, країн Балтії; західна - Північна Америка (Сполучені Штати Америки (далі США), Канада), Південна Америка (Аргентина, Бразилія, інші країни), Австралія, Західна Європа (Велика Британія, Німеччина, Франція, Італія), Центральна і Східна Свропа (Австрія, Чехія, Словаччина, Угорщина, Польща, Румунія), Азія (без країн колишнього Радянського Союзу), країни Африки.

Таку типізацію запропонував російський науковець українського походження В. Кабузан. За близькістю країни проживання до України науковець виділив ближнє: а) країни колишнього Союзу Радянських Соціалістичних Республік; б) суміжні з Україною держави Центральної Європи; та дальне зарубіжжя: а) країни Центральної та Західної Європи; б) країни Нового Світу (США, Канада, Аргентина, Бразилія, Парагвай, Уругвай, Австралія $)^{28}$.

Типізація різноманітних географічних об’єктів і явищ за найсуттєвішими ознаками $є$ одним із популярних методів суспільної географії. Ця типізація дає змогу розв'язати такі завдання: а) вказати чинники, які зумовили особливості розселення української діаспори; б) урахувати етнічні, мовні та культурні особливості країн проживання, які впливають на етногеографічні процеси в українській діаспорі; в) стати основою для поліпшення державної діаспоральної політики.

Розроблена нами типізація містить такі критерії: належність країни проживання до макрорегіону, період міграції українців, розселення українців, структура української діаспори та динаміка ії чисельності.

26 Попков В. «Классические диаспоры»: к вопросу о дефиниции понятия. Диаспоры. Москва, 2002. № 1. С. 7-22.

27 Дністрянський М. Етногеографія України. Львів : Видавничий центр ЛНУ імені Івана Франка, 2008. С. 154.

${ }^{28}$ Кабузан В. Украинцы в мире: динамика численности и расселения. 20-е гг. XVIII в. - 1989 г. : формирование этнических и политических границ украинского этноса. Москва : Наука, 2006. С. 3. 
Критерій макрорегіону поєднував у собі етнічні, мовні, релігійні та культурні особливості. Період міграції українців впливає на зв'язок 3 історичною батьківщиною та частку змішаних шлюбів, що в подальшому ускладнює етнічну ідентифікацію дітей.

Залежно від країни проживання можна виділити чотири групи зарубіжного українства: а) власне українська діаспора (Австралія, Азербайджан, Аргентина, Бразилія, Вірменія, Грузія, Естонія, Казахстан, Канада, Киргизстан, Латвія, Литва, Нова Зеландія, Парагвай, США, Таджикистан, Туркменістан, Узбекистан); б) українці, які переважно проживають на українських етнічних землях у складі інших країн (Румунія, Словаччина, Польща, Російська Федерація, Білорусь); в) середовища українських трудових мігрантів (Іспанія, Італія, Португалія, Чехія); г) країни, де поєднуються кілька критеріїв (Білорусь, Молдова, Польща, Російська Федерація) ${ }^{29}$.

Розселення українців впливає на збереження етнічної ідентичності, уживання української мови, рівень освіти, доступ до джерел існування, наявність українських організацій тощо. За характером розселення української діаспори можна виділити три іiї типи: а) проживання українців на етнічних землях у складі інших країн; б) зосередження українців у певному регіоні, що визначається природними, економічними чи політичними особливостями заселення; в) дисперсне розселення.

Вищезазначені критерії безпосередньо впливають на динаміку чисельності української діаспори. У країнах, де українці проживають на етнічних територіях, вищий рівень економічного розвитку та менша етнічна, культурна й релігійна дистанція, діаспора краще зберігає етнічну ідентичність.

Виділено десять чинників зменшення кількості української діаспори: асиміляція, військові конфлікти та нестабільна політична ситуація, культурна, мовна і релігійна дистанція з титульним етносом, інтеграція в російську діаспору, низький економічний розвиток країни, особливості ведення країною проживання етнічної політики, зміна поколінь, проблеми, пов'язані з набуттям громадянства, міграція в інші країни та рееміграція до України. Ці чинники й типізацію країн за динамікою чисельності української діаспори подано в узагальнювальних таблицях (табл. 2-3) 30 .

За цими критеріями ми здійснили типізацію країн, де проживає численна українська діаспора. Виділено вісім типів країн, у межах яких виокремлено дев'ятнадцять підтипів (табл. 4).

29 Зубик А. Українська діаспора: суспільно-географічне дослідження. Львів : Простір-М, 2019. С. 231.

${ }^{30}$ Там само. C. 233. 
Таблиця 2

Типізація країн за динамікою чисельності українців

\begin{tabular}{|c|c|c|}
\hline $\begin{array}{c}\text { ТиІІ } \\
\text { країн }\end{array}$ & Підтип країн & Країни \\
\hline \multirow{3}{*}{ I. } & $\begin{array}{l}\text { 1.1. Дуже високі темпи зменшення } \\
\text { чисельності українців, понад } 3 \% \text { на рік }\end{array}$ & $\begin{array}{l}\text { Вірменія, Таджикистан, } \\
\text { Туркменістан, Казахстан, Грузія, } \\
\text { Киргизстан, Узбекистан }\end{array}$ \\
\hline & $\begin{array}{l}\text { 1.2. Високі темпи зменшення } \\
\text { чисельності українців, } 2-3 \% \text { на рік }\end{array}$ & $\begin{array}{l}\text { Білорусь, Естонія, Латвія, Литва, } \\
\text { Російська Федерація, Словаччина }\end{array}$ \\
\hline & $\begin{array}{l}\text { 1.3. Середні темпи зменшення } \\
\text { чисельності українців, } 1-2 \% \text { на рік }\end{array}$ & Молдова, Румунія, Азербайджан \\
\hline \multirow{3}{*}{ II. } & $\begin{array}{l}\text { 2.1. Малі темпи збільшення } \\
\text { чисельності українців, до } 1 \% \text { на рік }\end{array}$ & Канада, Португалія \\
\hline & $\begin{array}{l}\text { 2.2. Середні темпи збільшення } \\
\text { чисельності українців, } 1-5 \% \text { на рік }\end{array}$ & Іспанія, Італія \\
\hline & $\begin{array}{l}\text { 2.3. Високі темпи приросту чисельності } \\
\text { українців, понад } 5 \% \text { на рік }\end{array}$ & США, Угорщина, Польща, Чехія \\
\hline
\end{tabular}

Таблиця 3

Чинники зменшення кількості українців у країнах проживання

\begin{tabular}{|c|c|c|c|c|c|c|c|c|c|c|}
\hline Країна & & 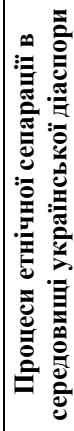 & 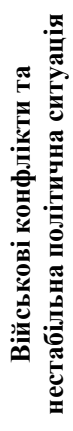 & 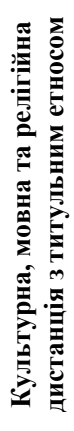 & 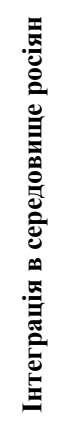 & 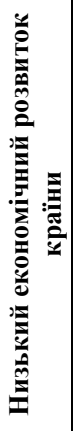 & 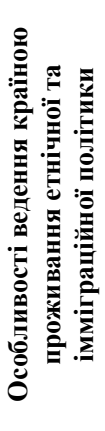 & 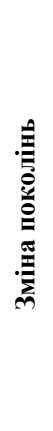 & 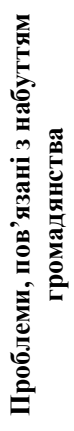 & 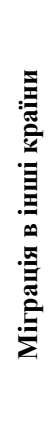 \\
\hline 1 & 2 & 3 & 4 & 5 & 6 & 7 & 8 & 9 & 10 & 11 \\
\hline Австралія & ++ & - & - & - & - & - & - & ++ & - & - \\
\hline Азербайджан & + & - & - & ++ & + & - & - & - & - & - \\
\hline Аргентина & $\begin{array}{c}++ \\
+\end{array}$ & - & - & - & - & - & - & ++ & - & - \\
\hline Білорусь & ++ & - & - & - & + & - & ++ & + & - & + \\
\hline Бразилія & $\begin{array}{c}++ \\
+\end{array}$ & - & - & - & - & - & - & ++ & - & - \\
\hline Вірменія & ++ & - & ++ & ++ & ++ & + & - & ++ & - & + \\
\hline Грузія & + & - & +++ & ++ & ++ & ++ & - & + & - & ++ \\
\hline Естонія & ++ & - & - & ++ & +++ & - & ++ & + & ++ & ++ \\
\hline Канада & + & + & - & - & - & - & - & + & - & - \\
\hline Казахстан & ++ & - & - & ++ & ++ & + & + & ++ & - & + \\
\hline Киргизстан & ++ & - & - & ++ & ++ & ++ & - & ++ & - & + \\
\hline Латвія & ++ & - & - & ++ & ++ & - & ++ & ++ & ++ & - \\
\hline Литва & ++ & - & - & ++ & + & - & + & + & + & - \\
\hline Молдова & + & - & + & - & + & + & - & - & - & ++ \\
\hline
\end{tabular}


Продовження таблиці 3

\begin{tabular}{|c|c|c|c|c|c|c|c|c|c|c|}
\hline $\mathbf{1}$ & $\mathbf{2}$ & $\mathbf{3}$ & $\mathbf{4}$ & $\mathbf{5}$ & $\mathbf{6}$ & $\mathbf{7}$ & $\mathbf{8}$ & $\mathbf{9}$ & $\mathbf{1 0}$ & $\mathbf{1 1}$ \\
\hline Польща & ++ & + & - & - & - & - & + & - & - & - \\
\hline Росія & ++ & + & + & - & - & - & ++ & ++ & - & + \\
\hline Румунія & ++ & + & - & - & - & - & + & + & - & - \\
\hline Словаччина & ++ & ++ & - & - & - & - & + & - & - & - \\
\hline США & ++ & + & - & - & + & - & + & - & - & - \\
\hline Таджикистан & $\begin{array}{c}++ \\
+\end{array}$ & - & + & ++ & + & ++ & - & + & - & + \\
\hline Туркменістан & $\begin{array}{c}++ \\
+\end{array}$ & - & + & ++ & + & ++ & + & + & - & + \\
\hline Угорщина & ++ & ++ & - & - & - & - & + & - & - & - \\
\hline Узбекистан & $\begin{array}{c}++ \\
+\end{array}$ & - & + & ++ & ++ & ++ & + & ++ & - & + \\
\hline
\end{tabular}

+++-велике значення; ++ - середнє значення; + -мало впливає; - - вплив дуже незначний або взагалі не проявлясться.

Таблиця 4

Типізація української діаспори за схожістю формування

\begin{tabular}{|c|c|c|c|}
\hline $\begin{array}{c}\text { TиI } \\
\text { країн }\end{array}$ & $\begin{array}{c}\text { Tериторіальна } \\
\text { належність }\end{array}$ & $\begin{array}{c}\text { Підтип } \\
\text { країн }\end{array}$ & Країна / група країн \\
\hline \multirow{6}{*}{. } & \multirow{6}{*}{$\begin{array}{c}\text { країни } \\
\text { колишнього } \\
\text { Радянського } \\
\text { Союзу }\end{array}$} & 1.1 & Російська Федерація \\
\hline & & 1.2 & Казахстан, Киргизстан \\
\hline & & 1.3 & Білорусь, Молдова \\
\hline & & 1.4 & Латвія, Литва, Естонія \\
\hline & & 1.5 & Азербайджан, Вірменія, Грузія \\
\hline & & 1.6 & країни Середньої Азії \\
\hline \multirow[b]{2}{*}{ II } & \multirow{2}{*}{$\begin{array}{c}\text { країни } \\
\text { Центрально- } \\
\text { Східної Європи } \\
\end{array}$} & 2.1 & Польща, Румунія, Угорщина, Словаччина \\
\hline & & 2.2 & Чехія \\
\hline \multirow{3}{*}{ III } & \multirow{3}{*}{$\begin{array}{c}\text { країни «нової» } \\
\text { міграції }\end{array}$} & 3.1 & Італія, Іспанія \\
\hline & & 3.2 & Португалія, Греція \\
\hline & & & Ізраїль \\
\hline \multirow[b]{2}{*}{ IV } & \multirow{2}{*}{$\begin{array}{c}\text { країни Свропи з } \\
\text { високим рівнем } \\
\text { економічного } \\
\text { розвитку }\end{array}$} & 4.1 & Франція, Німеччина, Велика Британія \\
\hline & & 4.2 & Австрія \\
\hline V & $\begin{array}{l}\text { країни кол. } \\
\text { Югославії }\end{array}$ & 5.1 & $\begin{array}{c}\text { Сербія, Словенія, Боснія і Герцеговина, } \\
\text { Чорногорія, Хорватія, Македонія }\end{array}$ \\
\hline \multirow{2}{*}{ VI } & \multirow{2}{*}{$\begin{array}{c}\text { країни Північної } \\
\text { Америки } \\
\end{array}$} & 6.1 & США \\
\hline & & 6.2 & Канада \\
\hline \multirow{2}{*}{ VII } & \multirow{2}{*}{$\begin{array}{c}\text { країни Південної } \\
\text { Америки }\end{array}$} & 7.1 & Бразилія, Аргентина \\
\hline & & 7.2 & Парагвай, Уругвай \\
\hline VIII & $\begin{array}{l}\text { Австралія й } \\
\text { Океанія }\end{array}$ & 8.1 & Австралія, Нова Зеландія \\
\hline
\end{tabular}

До першого типу країн ми віднесли країни колишнього Радянського Союзу, які поділено на шість підтипів. У Російській Федерації українці проживають на українських етнічних територіях, великою є українська 
трудова діаспора. Переселення українців до Казахстану та Киргизстану відбувалося одночасно із сільськогосподарським освоєнням земель, згодом - через їхню індустріалізацію. Білорусь і Молдова $є$ країнамисусідами України, тому українці на окремих територіях є автохтонним населенням, рівень їхнього економічного розвитку приблизно однаковий. Як країни 3 дуже відмінними культурою, мовою, ментальністю окремо виділено країни Балтики і Закавказзя. Отже, колишні азіатські республіки Радянського Союзу (крім Казахстану та Киргизстану) належать до шостого підтипу.

2. Країни Центрально-Східної Європи, куди належать країни-сусіди України: Польща, Угорщина, Словаччина та Румунія. Це країни-члени Європейського Союзу, рівень життя в них вищий, ніж в Україні. Українці переважно живуть там на етнічних територіях, до цих країн спрямована українська трудова міграція. Чехія, яка входить до другого підтипу, приймала українську політичну еміграцію між двома світовими війнами, а після проголошення незалежності України сюди спрямована сучасна українська трудова міграція.

3. Країни «нової» міграції. Від початку XX ст. і до проголошення незалежності України українська міграція до цих країн мала спорадичний характер. До цих країн переважно їхали заробітчани, пік прибуття яких припадає на початок XXI ст. і пов'язаний із процесами легалізації трудових мігрантів. Об'єктивно встановити кількість українців немає змоги через те, що значна частина українців перебувають тут нелегально. Окремим підтипом виділено Ізраїль, куди українці мігрували як члени змішаних сімей.

4. Країни Свропи 3 високим рівнем економічного розвитку. Українська діаспора цих країн переважно сформувалася після закінчення Другої світової війни. Сучасна українська трудова міграція ускладнена особливостями міграційного законодавства цих країн ${ }^{31}$.

5. Країни колишньої Югославії. Українська міграція до регіону відбувалася наприкінці XIX ст. Українці компактно проживають в окремих регіонах Боснії та Герцеговини, Сербії і Хорватії. 3 огляду на територіальну віддаленість регіону від України та нестабільну політичну ситуацію, там проживає незначна кількість українців.

6. Країни Північної Америки, де окремими підтипами виділено США та Канаду. Ці країни мають понад столітній досвід приймання українських мігрантів, фактично з кінця XIX ст. сюди безперервно відбувається українська міграція. За чисельністю української діаспори це друга (Канада) і третя (США) країни.

7. Країни Південної Америки. Аргентина та Бразилія, як і США та Канада, були одними з перших країн, які приймали українських

31 Зубик А. Українська діаспора: суспільно-географічне дослідження. Льві : Простір-М, 2019. С. 237. 
мігрантів. Особливості проведення переписів населення у цих країнах не дають змоги об'єктивно встановити кількість українців. Українська міграція до цих країн припинилася у 60-70-і pp. XX ст., міграція українців на сучасному етапі $є$ одиничною. Парагвай та Уругвай, як і Аргентина та Бразилія, прийняли останніх українських мігрантів у 6070-i pp. XX ст., проте вони згодом переселилися до Канади та США.

8. Австралія й Океанія. Зважаючи на територіальну відірваність, у цьому регіоні проживає незначна частка української діаспори.

\section{ВИСНОВКИ}

Попри різноманіття підходів до поняття «діаспора», його усталеного розуміння немає. Загалом діаспору визначають як частину етносу, яка внаслідок негативних явищ чи подій проживає поза межами своєї історичної батьківщини. Через таке трактування до діаспори відносять трудових мігрантів, біженців, іммігрантів.

Чинниками утворення діаспори науковці часто називають недобровільне переселення (унаслідок переслідувань через етнічну, мовну чи релігійну/конфесійну належність або природні катаклізми) чи міграцію з метою пошуку крашої долі (трудова міграція). У першому випадку через травму, пов'язану із примусовим переселенням, виникають діаспори. Основною ідеєю функціонування таких спільнот може бути протидія владі на їхній історичній батьківщині чи ідея незалежної держави (у випадку «бездержавних» діаспор це може бути звільнення від залежності або офіційне визнання їхньої країни).

За добровільної (трудової) міграції люди передусім орієнтуються на території, де $\epsilon$ попит на робочу силу. Утворенню діаспор передує етап іммігрантських спільнот. На відміну від діаспор, де люди об'єднуються на основі спільного етнічного походження, іммігрантські спільноти можуть об'єднуватись на основі регіону походження, мови спілкування чи релігії. Також такі спільноти є динамічними за своїм складом. Часто міграція може мати сезонний характер чи відбуватися до країн, де вищий рівень заробітної плати. Трансформацію іммігрантських спільнот у діаспори можна спостерігати на прикладі українських діаспор у країнах «нової» міграції - Іспанії, Італії та Португалії. Спочатку міграція туди була нелегальною, проте завдяки процесам лібералізації імміграційного законодавства частина українців легалізували своє перебування. Водночас виникають різні організації, які сприяють їхній консолідації. Це можуть бути книжкові клуби, аматорські театри, об'єднання за інтересами тощо. Наявність та функціонування організацій у діаспорі в низці визначень $є$ ключовою.

Належність країни проживання, період міграції до країни, характер розселення українців, структура діаспори (переважання «класичної» діаспори чи трудових мігрантів) впливають на ступінь збереження етнічної свідомості, рідної мови тощо. Залежно від типу спільноти 
(власне українська діаспора, українці, які проживають на українських етнічних територіях у складі інших країн, українські трудові мігранти) та країни проживання можна ефективно спланувати діаспорну політику України щодо діаспори.

\section{АНОТАЦІЯ}

Стаття присвячена розгляду й аналізу підходів до трактування поняття «діаспора» та ії типізації. Діаспорна проблематика $\epsilon$ надзвичайно актуальною для географії, за допомогою географічного підходу можна уточнити особливості розселення, просторові аспекти суспільних процесів, які відбуваються в діаспорі, пояснити дію різноманітних чинників, що впливають на процес формування й розвитку діаспор. Ця проблематика є актуальною для України, адже поза межами історичної батьківщини проживають мільйони українців. Різний час утворення українських діаспор, близькість до України, особливості країни проживання, наявність нової міграції прямо впливають на збереження етнічної та мовної ідентифікації.

У результаті дослідження проаналізовано підходи до трактування поняття «діаспора», виділено головні ознаки, за якими науковці відрізняють діаспори від інших спільнот. Здійснена у статті типізація країн, де проживає численна українська діаспора, ураховує низку критеріїв, які дали змогу виділити вісім типів країн. Із таким підходом можна об'єктивніше здійснювати порівняльний аналіз українських діаспор, які функціонують у країнах однієї групи. Також розроблену нами типізацію країн, де проживає українська діаспора, можна використати для налагодження діаспорної політики України.

\section{ЛITЕРАТУРА}

1. Алієва М. Діаспора: історія, історіографія та спроба уточнення поняття. Вісник Київського національного університету імені Тараса Шевченка. Історія. Київ, 2006. Вип. 86. С. 63-68.

2. Алієва М. Різні тлумачення терміна «діаспора». Етнічна історія народів Свропи. Київ, 2008. Вип. 24. С. 63-68.

3. Арутюнов С. Диаспора - это процесс. Этнографическое обозрение. Москва, 2000. № 2. С. 74-78.

4. Аствацатурова М. Современные диаспоры: сложности теоретического осмысления. Этнические проблемы современности. 2001. Вып. 7. С. 41-46.

5. Брубейкер Р. Диаспоры катаклизма в Центральной и Восточной Европе и их отношение с родинами. Диаспоры. Москва, 2005. № 3. C. $44-71$.

6. Винницький М. Україна і діаспора - можливості формування світового українства. Культурні зв'язки Донеччини з украӥнським 
зарубіжжся : матеріали Науково-практичної конференції, м. Донецьк, 17 грудня 2004 р. Донецьк, 2004. С. 17-22.

7. Винниченко I. Закордонне українство. Культурні зв'язки Донеччини з украйнським зарубіжжям : матеріали Науково-практичної конференції, м. Донецьк, 17 грудня 2004 р. Донецьк, 2004. С. 8-14.

8. Годованська О. Новітня українська діаспора: трудові мігранти в Італії, Іспанії та Португалії. Львів : Ін-т народознавства НАН України, 2011. $191 \mathrm{c}$.

9. Дністрянський М. Етногеографія України. Львів : Видавничий центр ЛНУ імені Івана Франка, 2008. 232 с.

10. Дятлов В. Диаспора: попытка определиться в понятиях. Диаспоры. Москва, 1999. № 1. С. 8-24.

11. Свтух В., Трощинський В., Швачка О. Українська діаспора. Соціологічні та історичні студії. Київ : Фенікс, 2003. 228 с.

12. Заставний Ф. Східна українська діаспора. Львів : Світ, 1992. 176 с.

13. Зубик А. Українська діаспора: суспільно-географічне дослідження. Львів : Простір-М, 2019. 440 с.

14. Исторический словарь. URL: http://mirslovarei.com/content_his/ Diaspora-1402 (дата звернення: 23.07.2017).

15. Кабузан В. Украинцы в мире: динамика численности и расселения. 20-е гг. XVIII в. - 1989 г.: формирование этнических и политических границ украинского этноса. Москва : Наука, 2006. 658 с.

16. Канукова 3. Диаспора: функциональный анализ термина. Вестник Владикавказского научного центра. Владикавказ, 2011. № 4. C. 23-28.

17. Карпова Ю. Этнодемографические аспекты миграционных процессов в России и Украине. Социс. Москва, 2005. № 12. С. 94-102.

18. Ким А. Этнополитическое исследование современных диаспор (конфликтологический аспект) : автореф. дис. ... докт. полит. наук. Санкт-Петербург, 2009. URL: http://vak.ed.gov.ru/common/img/uploaded/ files/vak/annocements/politich/2009/06-04/KimAS.rtf (дата звернення: 26.06.2017).

19. Кондратьева Т. Диаспоры в современном мире: эволюция явления и понятия. URL: http://www.perpectivy.info (дата звернення: 26.06.2017).

20. Коннор У. Диаспоры: транснациональное самосознание и политика в странах исхода. Диаспоры. Москва, 1999. № № 2-3. С. $40-51$.

21. Курас I. Етнополітологія. Перші кроки становлення. Київ : Генеза, 2004. 736 с.

22. Лаллукка С. Диаспора. Теоретический и прикладной аспекты. Социс. Москва, 2000. № 7. С. 91-98.

23. Левин 3. Менталитет диаспоры : системный и социокультурный анализ. Москва : Ин-т востоковедения РАН ; Крафт, 2001. 176 с. 
24. Мала енциклопедія етнодержавознавства / за ред. Ю. Римаренко. Київ : Генеза, 1999. 942 с.

25. Милитарев А. О содержании термина «диаспора» (к разработке дефиниции). Диаспоры. Москва, 1999. № 1. С. 24-33.

26. Попков В. «Классические диаспоры»: к вопросу о дефиниции понятия. Диаспоры. Москва, 2002. № 1. С. 7-22.

27. Професор Володимир Кубійович / упоряд. О. Шаблій. Львів : Видавничий центр ЛНУ імені Івана Франка, 2006. 378 с.

28. Семенов Ю. Этнос, нация, диаспора. Этнографическое обозрение. Москва, 2000. № 2. С. 64-73.

29. Стрельченко С. Диаспора как субъект социально-экономических процессов современности. Энергия. 2006. № 7. С. 65-68.

30. Тишков В. Исторический феномен диаспоры. Этнографическое обозрение. Москва, 2000. № 2. С. 43-63.

31. Тощенко Ж. Диаспора как объект социологического исследования. Социс. Москва, 1996. № 12. С. 37-45.

32. Трощинський В. Українці у світі. Київ : Альтернативи, 1999. 352 с.

33. Хабибулина Н. Диаспора: сущность, социально-философские аспекты развития: на материалах Бурятии : автореф. дис. ... канд. филос. наук: 09.00.04. Улан-Удэ, 2003. 20 с.

34. Шеффер Г. Диаспоры в мировой политике. Диаспоры. Москва, 2003. № 1. C. 162-184.

35. Armstong J. Mobilized and proletarian Diasporas. American political sciences review. 1976. Vol. 70. № 2. P. 393-408.

36. Clifford J. Diasporas. Cultural Anthropology. Washington, 1994. Vol. 9. № 3. P. 302-338.

37. Cohen R. Global Diasporas: an introduction. New York ; London, 1999. $228 \mathrm{p}$.

38. Dahan M. Ethnicgroups and distantshrinking communication technologies. Nationalism and ethnicpolitics. 2001. Vol. 7. № 1. P. 25-40.

39. Esman M. Diasporas in international relations. Modern Diasporas in international politics. New York, 1986. P. 333-349.

40. Safran W. Diasporas in modern Societies: myths of Homeland and return. Diaspora. 1991. Vol. 1. № 1. P. 83-95.

41. Sheffer G. A new field of study: modern Diasporas in international politics. Modern Diasporas in international politics. London, 1986. P. 1-15.

Information about author: Zubyk A. I.,

Candidate of Geographical Sciences, Associate Professor at the Department of Geography of Ukraine Ivan Franko National University of Lviv 41, P. Doroshenka str., Lviv, 79007, Ukraine 